\title{
DIFFERENCES IN THE DEVELOPMENT OF THE SZCZECIN LAGOON AREA IN THE LATE GLACIAL AND HOLOCENE BASED ON THE GEOCHEMICAL ANALYSIS OF CARBONATE SEDIMENTS FROM LAKE NOWOWARPIEŃSKIE (NW POLAND)
}

\author{
AGNIESZKA STRZELECKA', RAFAE WRÓBEL 2
}

\begin{abstract}
This paper presents the results of geochemical analysis performed for the more-than-10-m-long core of sediments derived from Lake Nowowarpieńskie. Contrary to what its geographical name would suggest, it is in fact a peripheral bay of the Szczecin Lagoon (NW Poland). A characteristic feature of the sedimentary cover of this water body is the several-metrethick layer of lacustrine chalk, which is unique in the lithology of the sediments of today's Szczecin Lagoon. This sediment has been analysed using atomic absorption spectrometry (AAS), energy-dispersive X-ray spectroscopy (EDS) and scanning electron microscopy (SEM) imaging. The chalk sediment from Lake Nowowarpieńskie is of chemical origin, bearing no fragments of vascular plants, but only traces of C-org in the form of small plant remains. The analysis of individual crystals using the EDS method also show Ca contents of over 99\%. SEM images reveal that the sediment is characterised by a loose, disordered packing of individual crystals, often combined to form aggregates with a tabular structure. The individual calcite grains are usually a few micrometres in size, while developed ones are mostly hypidiomorphic and show signs of corrosion. The sedimentation of the lacustrine chalk indicates that the post-glacial natural development of this part of what today constitutes Szczecin Lagoon differed from that of the rest of the lagoon. This sediment was deposited in a shallow but fertile isolated lake. The full profile of sediments from Lake Nowowarpieńskie reveals its distinct bipartite character, indicating two main stages of its evolution: carbonate and post-carbonate. In the first, the water body showed similarities to the neighbouring lakes of the Wkrzańska Plain. Its evolution was driven by climatic factors. The second stage was initiated by a palaeohydrological factor Littorina transgression, which resulted in the lake being included into the hydrological system of the Szczecin Lagoon.
\end{abstract}

Key words: lacustrine chalk, geochemistry, energy dispersive spectroscopy, Littorina transgression

\section{Introduction}

The Szczecin Lagoon (NW Poland) is a key element of the hydrological system of the Odra River estuary. Its development, from the end of the Vistulian glaciation, was of complex and multi-stage character, as reflected in the sedimentary sequence. Extensive multidisciplinary research into the Great Lagoon (the eastern, Polish, part of the Szczecin Lagoon) has distinguished a series of sediments deposited in various sedimentary environments (Borówka et al. 2003, 2005a, b, 2017a, b; Osadczuk 2003; 2004; Witkowski et al. 2003).

The series of glacial sediments is represented by tills, with top sloping from the east towards the meridional axis of the Great Lagoon. They are overlain by a series of glaciofluvial and fluvial sediments deposited prior to the Allerød by meltwater from the ice margin located to the north as well as riverine pre-Odra water coming from the south. These sediments cover almost the entire area of the Great Lagoon and achieve a thickness of about $20 \mathrm{~m}$. Their lithofacial dichotomy is manifested by poor sorting of glaciofluvial sands and gravels and the presence of limestone fragments, as well as good sorting of fine-grained fluvial sands devoid of carbonates. Fluvial sediments were deposited in numerous channels of the braided pre-Odra River. Sedimentation in semi-terrestrial conditions in the Allerød and the early Holocene continued in oxbow lakes of the pre-Odra River, where limnic detritus gyttja and peat were deposited. The drastic change in sedimentary conditions is expressed by a series of marine sediments associated with the Littorina transgression during the Atlantic period. Its bottom consists of fine-grained and well-sorted sands overlain by sandy silts deposited in conditions

\footnotetext{
${ }^{1}$ University of Szczecin, Institute of Marine and Environmental Sciences, Mickiewicza 16, 70-383 Szczecin, Poland; e-mail: agnieszka.strzelecka@usz.edu.pl, ORCID: 0000-0002-6876-7334

2 West Pomeranian University of Technology in Szczecin, Faculty of Chemical Technology and Engineering, Pułaskiego 10, 70-322 Szczecin, Poland; e-mail: rafal.wrobel@zut.edu.pl, ORCID: 0000-0003-2593-0813
} 
of the gradual closure of the marine bay by the Wolin and Usedom spits. A characteristic feature of these sediments is the presence of numerous marine and brackish malacofauna shells, often preserved in alive position. The top part of the sedimentary cover consists of dark organic-mineral sediments containing freshwater malacofauna shells. These sediments are classified as gyttja and represent contemporary sedimentation under lagoonal conditions (Borówka et al. 2017a, b; Osadczuk 2004).

The sequence of sediments presented above is representative of the main basin of the Great Lagoon. However, in its peripheral bays, such as Lake Nowowarpieńskie, the sedimentary cover representing limnic and marine deposition is formed differently. The objective of the study is a lithogenetic characterisation of Lake Nowowarpieńskie sediments to indicate the individual development of this part of the today's Szczecin Lagoon. A feature distinguishing the sediment profile of this water body is the presence of carbonate sediments with a thickness of up to $5.5 \mathrm{~m}$ (Witkowski et al. 2009) that within the Szczecin Lagoon is unique to this location.

\section{Study area}

Contrary to what its geographical name implies, Lake Nowowarpieńskie is not an independent body of water, but a sharply indented bay of the Szczecin Lagoon on the axis between the Great Lagoon on the territory of Poland and Kleines Haff in Germany (Fig. 1). It is a transboundary water body, with the Polish-German border crossing it in the middle. The total area of Lake Nowowarpieńskie is $18 \mathrm{~km}^{2}$ and its part belonging to Poland is $8.9 \mathrm{~km}^{2}$. Its average depth is about $1.5 \mathrm{~m}$, and the maximum depth is about $2.0 \mathrm{~m}$. It is widest in the south, at $6.2 \mathrm{~km}$, and narrows northwards to only $750 \mathrm{~m}$. The water body is partially separated from the Szczecin Lagoon by the Altwarp Peninsula in the west and the Nowowarpieński and Grodzki Peninsulas in the east.

The water body is surrounded by the Wkrzanska Plain (physico-geographical mesoregion 313.23, according to Solon et al. 2018), which is built of thick sand series deposited at the end of the Pleistocene, being a trace of a shallow, extensive marginal lake (Borówka et al. 2017a). The low-lying shores of Lake Nowowarpieńskie are covered with peats developed during the Holocene (Dobracka 1980; reambulated by Chmal, Karbowniczak 2015). Lake Nowowarpieńskie is one of the least known water bodies of the Szczecin Lagoon. It has never been the subject of separate palaeogeographical studies.

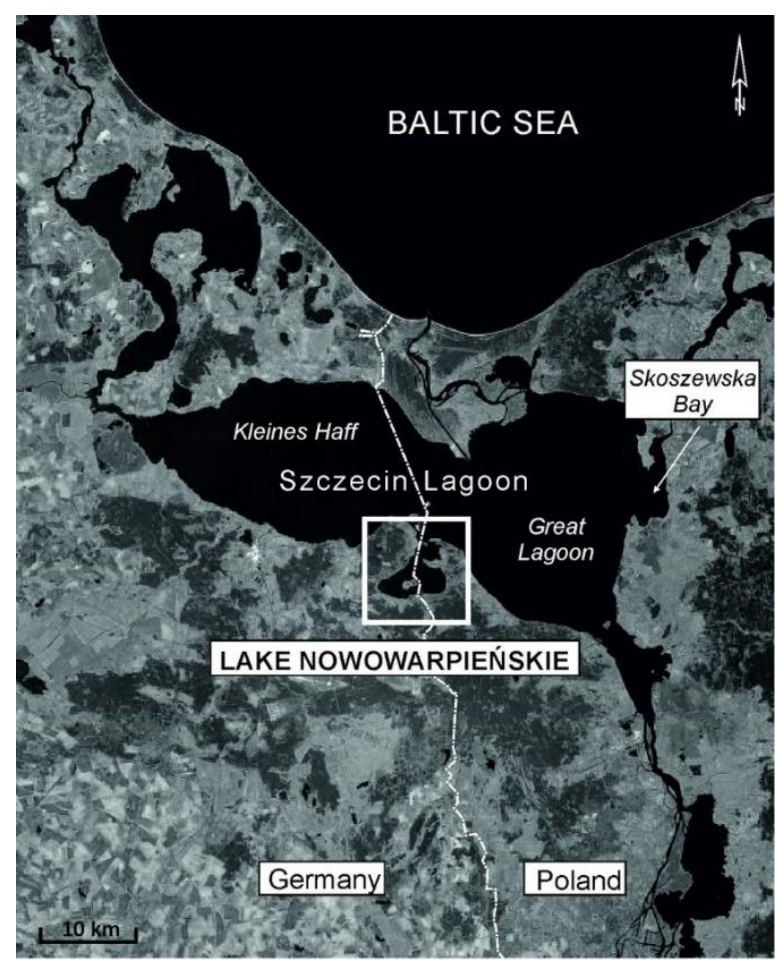

Fig. 1. Location of study area in Odra River estuary system

source of background: NASA Landsat

\section{Material and Methods}

The study is based on geochemical analysis of the sediment cores derived from the bottom of Lake Nowowarpieńskie (Fig. 2). The full sequence of sediments typical of this water body was acquired in the 10.85-m-long core JNW4. As the benchmark for the chronostratigraphy, the radiocarbon dating and time scale of core JNW1 from the close vicinity of the JNW4 was used (Fig. 2). In the geochemical analysis of core JNW4, the concentration of the following chemical elements were measured: $\mathrm{Na}, \mathrm{K}, \mathrm{Ca}, \mathrm{Mg}, \mathrm{Fe}, \mathrm{Mn}, \mathrm{Cu}, \mathrm{Zn}$, $\mathrm{Pb}$. For this purpose, we applied atomic absorption spectrometry (AAS) using a Solaar Unicam 969 flame atomisation spectrometer. The preparation of the sediment samples included microwave digestion in a mixture of nitric acid $\left(\mathrm{HNO}_{3}\right)$, hydrochloric acid $(\mathrm{HCl})$ and perhydrol $\left(\mathrm{H}_{2} \mathrm{O}_{2}\right)$ using a Berghof Speedwave 4 microwave digester. The results were obtained in $\mathrm{mg} / \mathrm{g}$ dry weight for macroelements and in $\mu \mathrm{g} / \mathrm{g}$ dry weight for microelements. 


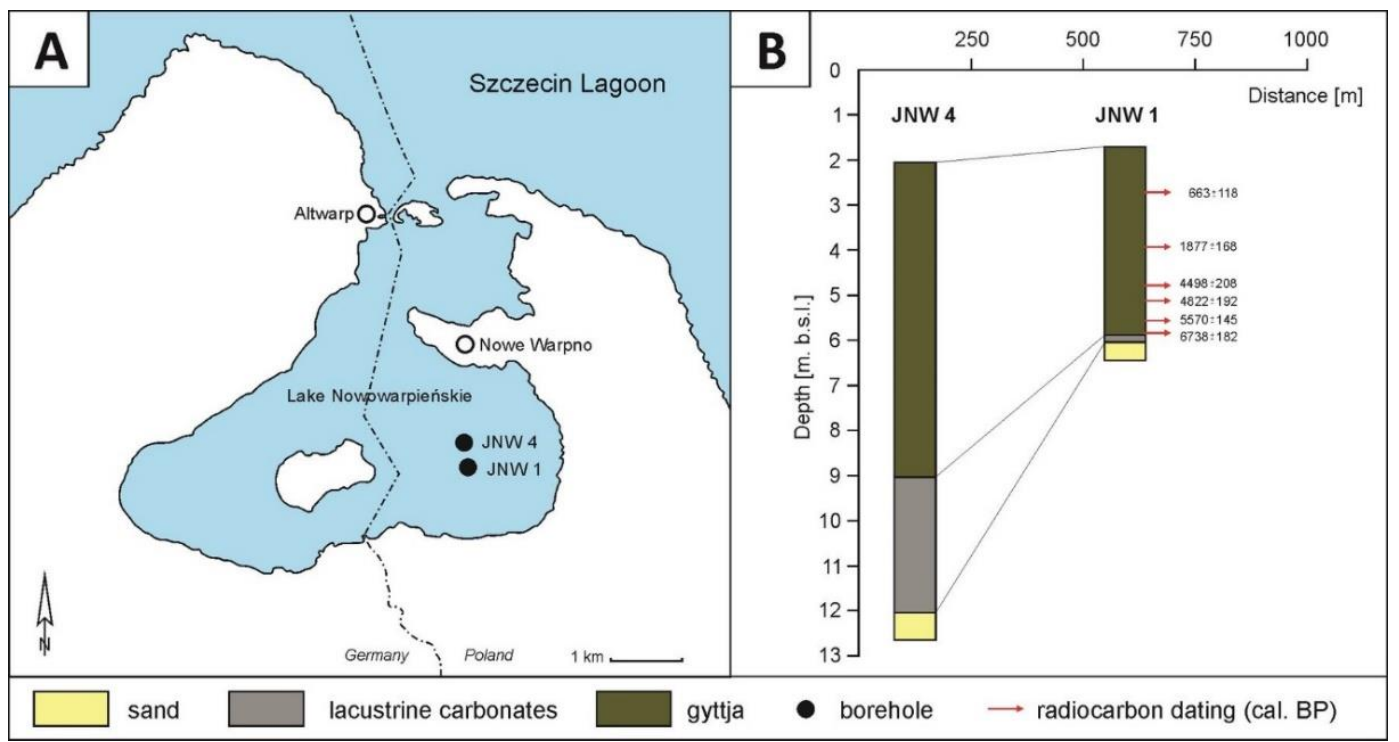

Fig. 2. Location of JNW4 and JNW1 cores (A) and their simplified lithology (B)

results of radiocarbon dating are from JNW1 core; radiocarbon dates calibrated by OxCal v.4.2.4 program (Bronk Ramsey, Lee 2013) using IntCal09 atmospheric curve (Reimer et al. 2009)

Organic matter content was determined by loss on ignition (LOI). The procedure involved freeze-drying of the naturally wet samples. These were then dried in a laboratory oven at $105^{\circ} \mathrm{C}$ and finally combusted in the Gallenkamp muffle furnace at $550^{\circ} \mathrm{C}$. The difference between the weight of the sample dried at $105^{\circ} \mathrm{C}$ and the weight of the sample after combustion, converted into percentages, represents the content of organic matter in the sediment. Both the geochemical analysis and loss on ignition were performed for samples taken at 5-cm depth intervals. The described procedure is commonly used for palaeo-environmental analyses of lakes in West Pomerania (e.g. Okupny et al. 2020).

Due to the unique occurrence of carbonate sediments in the Late Glacial and Holocene sedimentary cover of the Szczecin Lagoon, we focused especially on the analysis of the thick layer of lacustrine chalk from the JNW4 core, which was examined by energy-dispersive X-ray spectroscopy (known as EDS, EDX, EDXS or XEDS) in combination with scanning electron microscopy (SEM) imaging. EDS is an analytical technique that enables elemental analysis and chemical characteristics of a specimen. The elemental composition of the sample is measured through the interaction between the source of X-ray excitation (e.g. electrons) and the sample. The method is based on the principle that each element has a unique atomic structure reflected as an individual set of peaks in the X-ray spectrum (Abraham et al. 2020). SEM imaging gives information on the relief and structure of the sample (Khare et al. 2019). For analysis, a spectrometer from Malvern Panalytical, Royston, UK was used. The sample imaging was enabled by Hitachi SU8020 ultrahigh-resolution field-emission scanning electron microscope (UHR FE-SEM, Hitachi High-Technologies Corporation, Tokyo, Japan).

Five carbonate sediments samples from the core JNW4 were selected. They were obtained from the following depths of the core: $727.5 \mathrm{~cm}$, $787.5 \mathrm{~cm}, 847.5 \mathrm{~cm}, 907.5 \mathrm{~cm}$ and $967.5 \mathrm{~cm}$. The naturally fractured, dehydrated sediment samples served as the research specimen. Samples ranging in size from 0.2 to $0.7 \mathrm{~cm}^{2}$ were first mounted on a metal stub, then coated with $\mathrm{Cr}$.

\section{Results}

\section{Lithology}

The lithological profile of the JNW4 core obtained from the bottom of Lake Nowowarpieńskie (Fig. 3) begins with sandy sediments constituting a mineral substrate for younger lake sediments. These sediments are fine-grained, dark grey-olive sands with a small admixture of organic matter, in which it is impossible macroscopically to distinguish larger plant debris. Most likely, these are sands that can be correlated with the Late Glacial glaciofluvial and fluvial series commonly found in the main basin of the Great Lagoon. Above them, at a depth of 
$10.5 \mathrm{~m}$, a series of carbonate sediments begins that has a total thickness of up to $3.4 \mathrm{~m}$. The presence of these sediments is a feature distinguishing sedimentation in the water body in question.

It is important to note that a layer of lacustrine chalk has also been detected in the Skoszewska Bay - the eastern, shallow peripheral basin of the
Szczecin Lagoon (Mianowicz 2013), but its thickness there is only $16 \mathrm{~cm}$. Based on radiocarbon dating and pollen analysis results, that sedimentation began at the onset of the Holocene at the beginning of the Preboreal period (Mianowicz 2013). According to Borówka et al. (2017a), those sediments constitute the bottom of a series of early Holocene lacustrine sedimentation.

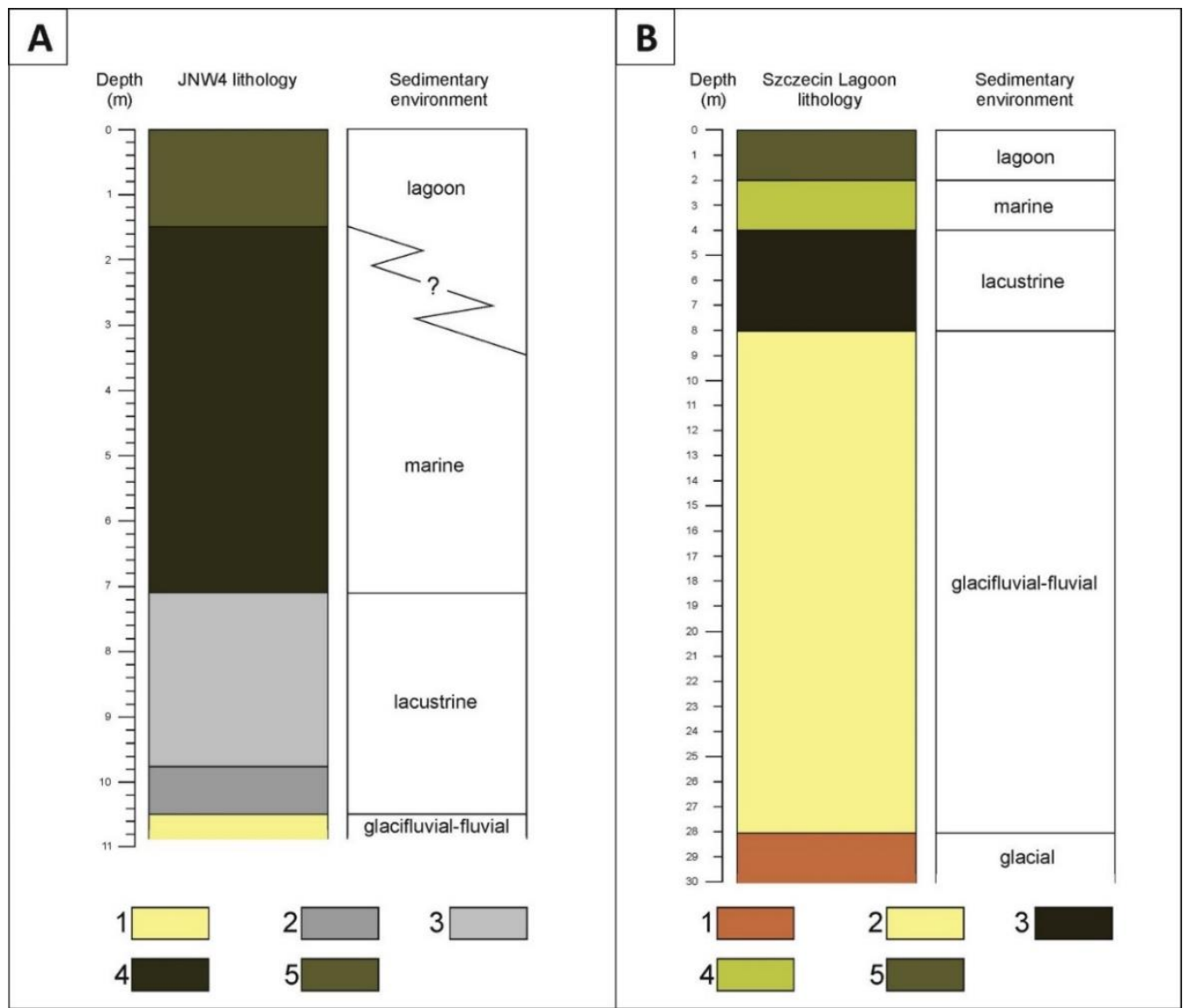

Fig. 3. JNW4 core lithology (A) related to schematic sediment profile of main basin of Szczecin Lagoon (B) based on Witkowski et al. 2009, Borówka et al. 2017a

A: 1 - sand, 2 - calcareous silt, 3 -lacustrine chalk, 4 - very-fine detritus gyttja, 5 - fine detritus gyttja B: 1 - till, 2 - sand, 3 - peat, gyttja, 4 - sand, sandy silt, 5 - gyttja, sandy silt, sand

Meanwhile, carbonate sedimentation in Lake Nowowarpieńskie starts with calcareous silt with a thickness of $0.7 \mathrm{~m}$. It is a beige-olive sediment, showing fine lamination in some places. It mainly consists of allochthonous silt with a slight admixture of fine-grained sand. The composition of the sediment lacks macroscopically visible plant debris. The presence of this sediment represents the beginning of sedimentation in an isolated lake water body. The silt layer is followed by lacustrine chalk. It is a beige-grey sediment devoid of lamination or noticeable organic fragments. Above a depth of $7.2 \mathrm{~m}$, the lacustrine chalk turns into a very fine detritus gyttja. In the transition layer, there are brown-coloured traces of larger pieces of decomposed wood. From that thin layer up to the top of the core, the sediment has similar lithological properties. Its characteristic feature is the presence of crushed shells of marine clams. However, at a depth of $5.62 \mathrm{~m}$, Cerastoderma glaucum (Piechocki, Wawrzyniak-Wydrowska 2016) was found in a living position. This proves a brackish environment in the water body associated with the direct inflow of marine waters during the Littorina transgression. Based on the macroscopic features of the sediment, it is not possible to determine the moment of transition from marine to post-Littorina lagoon sedimentation. The top $1.4 \mathrm{~m}$ of the JNW4 core consist of fine detritus gyttja. 


\section{Geochemical features}

On the base of the conducted analysis, seven geochemical zones have been distinguished (Fig. 4). However, geochemical zone $\mathrm{V}$ has been divided into sub-zones $\mathrm{A}$ and $\mathrm{B}$. The distinguished geochemical levels largely correspond to the lithological units of the core.

\section{JNW4-I (1085-1050 cm)}

The zone represents sedimentation of sand, poor both in organic matter (content approx. 2\%) and in the examined elements. This zone refers to the stage preceding the functioning of the lacustrine water body.
JNW4-II (1050-980 cm)

This zone relates to the first phase of the lake functioning, which is reflected in the sedimentation of the basal calcareous silt. The sediment has a high content of mineral matter (up to $98.5 \%$ ), largely composed of clay minerals. The supply of allochthonous matter from the catchment area is also marked by the increased content of $\mathrm{K}$ and $\mathrm{Mg}$. The values of the other examined elements also increase in this zone. Here, $\mathrm{Ca}$ has various values from 10 to $114 \mathrm{mg} / \mathrm{g}$. The $\mathrm{Fe} / \mathrm{Mn}$ ratio has relatively high values (around 100), indicating reducing conditions.

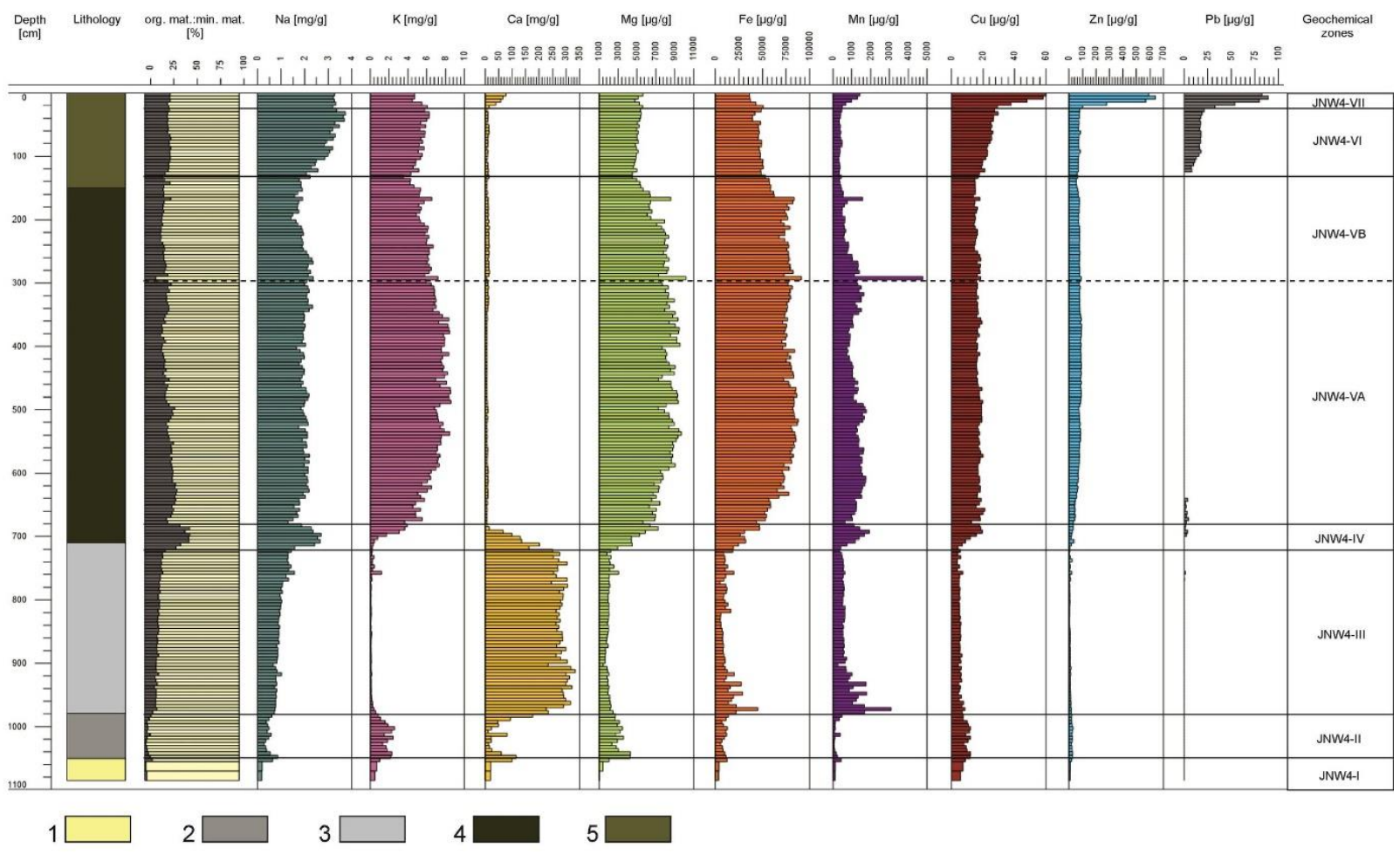

Fig. 4. Geochemical characteristics of JNW4 core sediments

based on the results, 7 main geochemical zones were distinguished representing separate stages of water body development: 1 - sand, 2 - calcareous silt, 3 - lacustrine chalk, 4 - very-fine detritus gyttja, 5 - fine detritus gyttja

\section{JNW4-III (980-720 cm)}

This is a record of sedimentation in an isolated lake dominated by groundwater supply. The share of organic matter increases here to about $15 \%$ and remains at a similar level in the entire zone. This level begins with an increase in $\mathrm{Fe}$ and $\mathrm{Mn}$, the content of which decreases in the upper part of the zone. The K content reaches the lowest values for the entire core, while the $\mathrm{Ca}$ content achieves its maximum, reaching $335 \mathrm{mg} / \mathrm{g}$. Changes in the $\mathrm{Fe} / \mathrm{Mn}$ ratio indicate more oxidising conditions.

\section{JNW4-IV (720-680 cm)}

This is a transition zone between the lacustrine chalk sedimentation and the gyttja sedimentation. This zone registers an extremely significant change in feeding type, and thus in the sedimentary conditions of the studied water body. In this zone, the share of organic matter clearly increases to $48 \%$, which is the highest value for the entire JNW4 core. An increase in Na content is observed along with the organic matter, which may indicate the periodic prevalence of evaporation over the 
supply of the water body. Moreover, a gradual increase in almost all elements, including $\mathrm{Pb}, \mathrm{Cu}$ and $\mathrm{Zn}$ is observed in this zone. The exception is the gradual decrease in $\mathrm{Ca}$ to the minimum values.

JNW4-V A, B (680-130 cm)

This zone corresponds to the stable conditions of sedimentation after the water body was included into the system of the so-called Szczecińska Bay (Borówka 2017) due to the encroachment of marine waters into land areas during a Littorina transgression. The share of organic matter fluctuates slightly here, remaining in the range of 20-30\%. The inflow of marine water was recorded in the form of an increase in the content of $\mathrm{Na}$ coming from the brackish Littorina Sea water. The concentration of $\mathrm{K}$ and $\mathrm{Mg}$ is also growing, indicating an increased supply of allochthonous matter. The inflow of alkaline marine water in this zone is manifested by chemical precipitation of Fe (Borówka 2007), which reaches maximum values. In this zone, the Mn content curve follows the course of the Fe content curve, assuming much lower values. In this section of the core, there is also a noticeable growth in the content of $\mathrm{Cu}$ and $\mathrm{Zn}$. The separation of sub-zones A and B results from the slight increase in the content of elements such as $\mathrm{K}, \mathrm{Mg}$, $\mathrm{Fe}, \mathrm{Mn}$ to the depth of $295 \mathrm{~cm}$. Then, their values successively decrease. This may express a gradual transition from marine to lagoon sedimentation.

JNW4-VI (130-25 cm)

This is a zone marked by an increase in the content of $\mathrm{Na}$ and, to a lesser extent, $\mathrm{K}$, a decrease in the content of $\mathrm{Mg}$ and $\mathrm{Fe}$ and a significant growth in the content of $\mathrm{Cu}$ and $\mathrm{Pb}$. The share of organic matter remains stable at $25 \%$. This zone represents sedimentation under lagoonal conditions with a significant influence of human activity.

JNW-VII $(25-0 \mathrm{~cm})$

The top part of the core corresponds to present-day sedimentation with strongly marked human industrial activity, manifested by contamination of the sediment with metals such as $\mathrm{Cu}$ (up to $60 \mu \mathrm{g} / \mathrm{g}$ ), $\mathrm{Zn}$ (up to $640 \mu \mathrm{g} / \mathrm{g}$ ) and $\mathrm{Pb}$ (up to $90 \mu \mathrm{g} / \mathrm{g}$ ), which reach their maximum values for the analysed sediment core.

\section{Characteristics of the lacustrine chalk from Lake Nowowarpieńskie}

Calcium carbonate $\mathrm{CaCO}_{3}$, with a slight admixture of magnesium carbonate, occurs in the sediments of many lakes in the Polish Lowland (Rutkowski
2007). Despite carbonate deposits being widespread in the Holocene sedimentary cover of the lakes, their classifications differ from each other. According to Pentecost (2009), lacustrine chalk is a sediment containing more than $50 \%$ of dry weight $\mathrm{CaCO}_{3}$ in the inorganic fraction. By contrast, classifications by Markowski (1980) and Rutkowski (2007) define carbonate sediments as follows:

$$
\begin{array}{ll}
\text { - }>80 \% \mathrm{CaCO}_{3} & \text { lacustrine chalk } \\
\text { - } 40-80 \% \mathrm{CaCO} & \text { chalk gyttja } \\
\text { - }<40 \% \mathrm{CaCO}_{3} & \text { gyttja }
\end{array}
$$

This may be also compared to the official German classification (AG Geologie 2021) defining lacustrine chalk as a sediment containing $>95 \%$ of $\mathrm{CaCO}_{3}$. In this case, if the content of organic matter in the sediment exceeds 5\%, it is regarded as carbonate gyttja. Moreover, $\mathrm{CaCO}_{3}$ can be of biochemical and/or chemical origin. According to Pentecost (2009), biogenic marl can be created by deposition primarily as the result of in-lake photosynthesis, both by Charophyta growth and by sedimentation of calcareous phytoplankton oncoids of Cyanophyceen (see also Schäfer 1973). Chara marls can be of benthic character and form in shallow lakes of water depth not exceeding $5 \mathrm{~m}$. In a deeper water body, $\mathrm{CaCO}_{3}$ may precipitate within the water column. The Chara calcification process has been featured in many works (e.g. Walker 1983; Raven et al. 1986). The studies revealed that calcification begins within the alkaline surface areas of the intermodal Chara cells and proceeds until the entire plant is filled in, which may be finally accompanied by inorganic precipitation. By contrast, abiogenic marls may be created by $\mathrm{CO}_{2}$ evasion (e.g. travertine sediments) or by incoming allochtonous carbonates (clastic marls). Regular freezing and intense evaporation may also contribute to abiogenic marl precipitation (Pentecost 2009).

The chalk from Lake Nowowarpieńskie is a carbonate sediment of chemical origin. Its precipitation from the aqueous solution was most likely initiated by the activity of plant organisms (Characeae). In the lacustrine chalk of the analysed water body, no fragments of vascular plants were found, but traces of C-org in the form of small plant remains were. It is assumed that the original amount of organic matter in the lacustrine chalk could have been much greater and that organic matter may have decomposed and been discharged only as a result of post-sedimentation changes. Similar to travertine, where a complete oxidation of plant material can take place in a short time (Schäfer 1973), similar processes can take place in fresh water bodies well enriched with oxygen. 


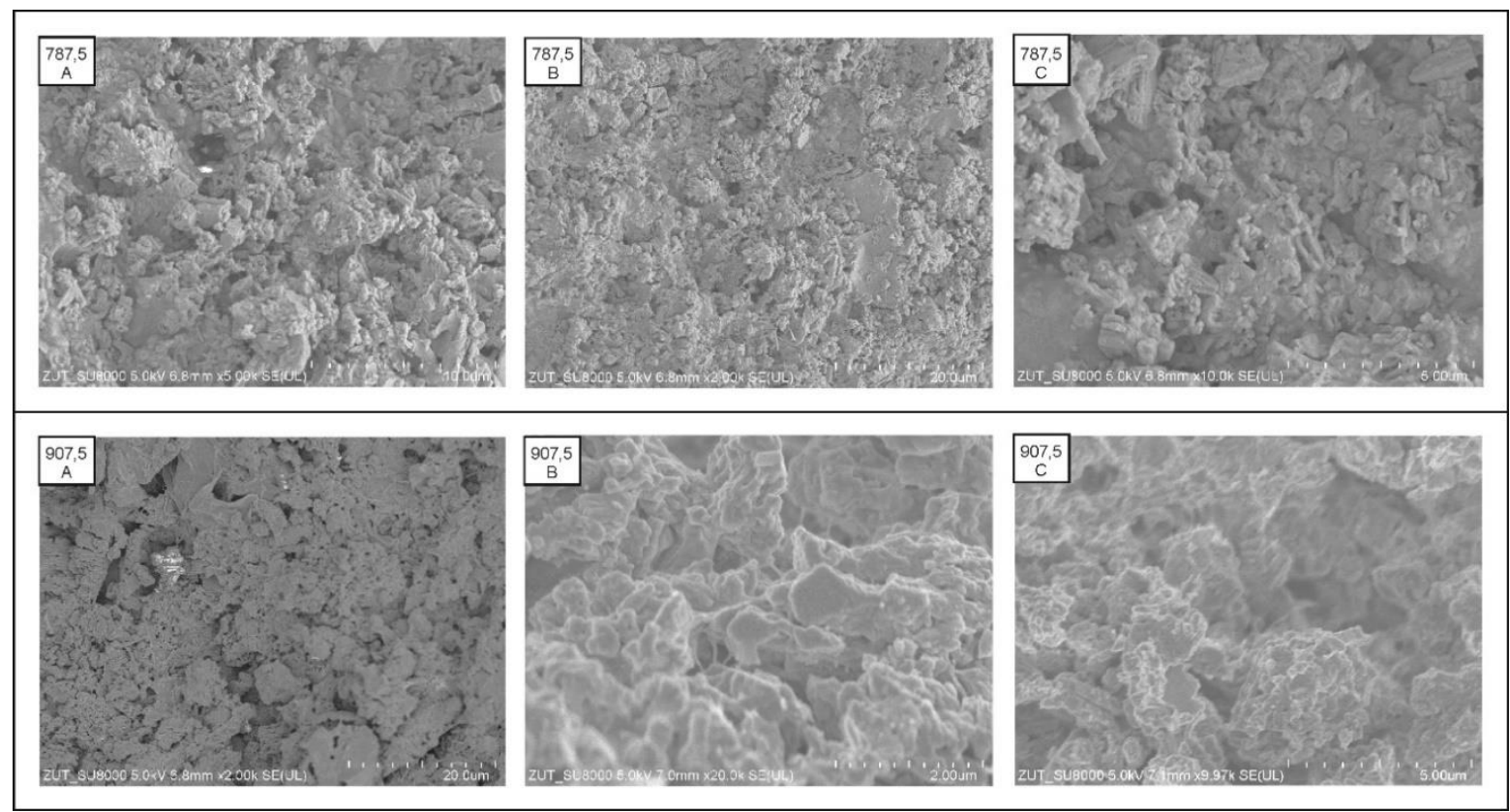

Fig. 5. Scanning electron microscopy imaging of samples 787.5 and 907.5

787.5 A - Calcite crystals as aggregates of tabular and pillar structure. Top left corner: one crystal of secondary ore mineral (probably pyrite); $787.5 \mathrm{~B}$ - example of porous texture of lacustrine chalk with secondary intergranular fillings of pore space due to cryptocrystalline flakes-like calcite binders; $787.5 \mathrm{C}$ - detailed picture of single pillar and cobble-like (broken pillars?) calcite crystals

907.5 A and B - Detailed image of calcite crystals in the form of secondary-etched, tabular aggregates. Note the high porosity of the sediment (complete absence of cement and other intergranular filling); $907.5 \mathrm{C}$ - example of a lacustrine chalk with different formation of crystals (bars, plates, radial and tabular aggregates, secondary flakes-like calcite binders). Right: one ore-crystal (pyrite?)

Images taken by electron microscope (Fig. 5) allowed shapes of individual grains/crystals of lacustrine chalk from Lake Nowowarpieńskie to be recognised. In general, the examined sediment is characterised by a loose, disordered packing of individual crystals, which are often combined to form aggregates with a tabular structure. The individual calcite grains are usually a few micrometres in size, and the developed ones are mostly hypidiomorphic and show signs of corrosion (etching) on the surface. Between the individual calcite grains, there are often free spaces not filled with any secondary cement, which is responsible for the high porosity of the sediment. In some cases, however, secondary intergranular fillings of the pore space due to cryptocrystalline calcite binders have also been observed.

Chemically, the lacustrine chalk from Lake Nowowarpieńskie is characterised by high $\mathrm{Ca}$ and low $\mathrm{Mg}$ contents. In the sections of the lacustrine chalk profile not contaminated with allochthonous material, the $\mathrm{Ca} / \mathrm{Mg}$ ratio varies from 100 to 185. Micro-area analysis carried out for individual crystals using the EDS method also show $\mathrm{Ca}$ contents of over $99 \%$ (e.g. sample 725.5, base 5).

\section{Discussion}

Based on the geochemical record in the sediment core JNW4 from Lake Nowowarpieńskie, supported by radiocarbon dating from the neighbouring JNW1 core, an initial attempt can be made to reconstruct the individual development of the analysed body of water.

\section{$\underline{\text { Stage 1: pre-lacustrine development }}$}

This stage is documented by the sandy sediments constituting the bottom of the JNW4 core. They were deposited in terrestrial conditions, in a glaciofluvial or fluvial environment. These sediments are the mineral base of the depression where the later lake developed. The genesis of this basin is not known so far. Most probably, as in the case of lake Ahlbecker See on the Wkrzańska Plain ( $2.5 \mathrm{~km}$ south of the Nowowarpieńskie Lake), it could have been a depression preserved with a dead-ice block (De Klerk 2005).

\section{Stage 2: Initial lacustrine environment}

The exact moment of initiation of lake sedimentation is not recognised yet. It was presumably in 
the Late Glacial or early Holocene, when permafrost and buried dead-ice blocks thawed. Groundwater enriched in $\mathrm{CaCO}_{3}$ began to circulate in the sandy sediments of the Wkrzańska Plain. The substance is commonly found in sediments of glacial environments. In the glacial till of the Vistulian glaciation its generalised content is estimated at $7.6 \%$. Its source were Palaeozoic and Mesozoic carbonate rocks of the central and western Baltic and the bedrock of north-west Poland (Bukowska-Jania 2003). In the study area, the top of carbonate rocks of Upper Cretaceous age are located at a relatively small depth of $24 \mathrm{~m}$ below the surface. They form the Nowe Warpno anticline structure, with the fold axis stretching from NW to SE across the Wkrzańska Plain and Lake Nowowarpieńskie (Dobracka 1980). The trace of the initial lake sedimentation stage at the site is calcareous silt with varying $\mathrm{CaCO}_{3}$ content. These changes are reflected in the sediment lamination. The layers with predominant allochthonous matter alternate with those where authigenic calcareous matter prevails. Such features indicate periodic changes in lake supply. The most significant process was the supply of mineral matter from the catchment, most likely by surface runoff together with aeolian transport. Nevertheless, periods of $\mathrm{CaCO}_{3}$-enriched groundwater supply are recognisable.

\section{Stage 3: lacustrine carbonate sedimentation}

Carbonate sedimentation gradually increases until it becomes the dominant process in the water body. It was initiated by climate change leading to the degradation of permafrost and subsequent water release. The water body was supplied with $\mathrm{CaCO}_{3}$-enriched groundwater, leaching and circulating in the immediate vicinity of the lake. The carbonate-rich glacial tills not only underlie the sandy sediments of the Wkrzańska Plain, but also surround the area in the form of a ground moraine to the west and south. After the groundwater reached the lake basin, the pressure dropped, causing the release of $\mathrm{CO}_{2}$ into the atmosphere, which resulted in a decrease in $\mathrm{pH}$. On the other hand, the increase in environmental alkalinity was supported by $\mathrm{CO}_{2}$ assimilation associated with the photosynthesis of aquatic plants. In this way, an environment that prevails over the precipitation of carbonates was created. This process was additionally aided by the physiological encrustation of Characeae tissues by $\mathrm{CaCO}_{3}$. The complex mechanism led to the deposition of a thick layer of lacustrine chalk with an extremely high
$\mathrm{CaCO}_{3}$ content that is unique within the lithological profile of today's Szczecin Lagoon. Such a significant accumulation of sediment indicates the intensity and duration of the calcite precipitation process. The chalk deposition probably took place in a small, shallow and fertile lake with welldeveloped communities of Characeae. During the sedimentation of the lacustrine chalk, the environmental conditions were stable, as expressed by the measured homogeneous chemical parameters. The period of carbonate deposition in the conditions of an isolated lake most likely ends with a decrease in the depth of the water body or even with periodical drying out. Carbonate deposits of varying thickness are also an important element of the lithological profile of lake Ahlbecker See. As indicated by radiocarbon dating and palynological analyses, carbonate sedimentation began before $10500 \mathrm{cal}$. year BP in this water body. (Herking 2002; Jahns, Herking 2002; De Klerk 2005). Borówka et al. (2017a) classifies the chalk sediments of Lake Nowowarpieńskie as one of the lithofacies of the lacustrine-swamp series of the Szczecin Lagoon sediments. However, a closer look shows that the development of this water body at this stage is more similar to the development of the lakes of the Wkrzańska Plain.

\section{Stage 4: sedimentation influenced by marine and lagoon water}

The most important event in the natural development of Lake Nowowarpieńskie is a radical change in the method of feeding. The transition from $\mathrm{CaCO}_{3}$-enriched groundwater to saline marine water is documented in the sedimentary cover of the water body. This is related to the progressive Littorina transgression, which began to cover the floodplain of the pre-Odra River around 7300 cal. BP (Borówka et al. 2017a). Under the influence of this extremely important palaeohydrological event, the previously isolated lake was included in the hydrological system of the marine bay of the time (known as the Szczecin Bay). As a result, the sedimentation of organic-mineral sediments, classified as gyttja, began (Osadczuk 2004). Based on the dating of the bottom of these sediments in the JNW1 core, the beginning of gyttja sedimentation can be determined at $6700 \mathrm{cal}$. $\mathrm{BP}$, i.e. at a later stage of transgression. The deposition of marine sediments in Lake Nowowarpieńskie differs from that found in the main basin of the Szczecin Lagoon, where fine sands, silty sands and sandy silts were accumulated (Borówka et al. 2017a). The determinant of direct inflow of saline waters to the water body is the 
presence of marine mollusc shells (even in alive position) found in the sediment. In the main basin of the Szczecin Lagoon, where lagoon gyttjas rest on the sandy sediments of the marine series, the boundary between two different sedimentary environments is clear. On the other hand, in Lake Nowowarpieńskie, this transition zone is blurred, as indicated by the lithological and geochemical features of the sediments. The influx of Littorina Sea water interrupted the carbonate sedimentation stage of Lake Nowowarpieńskie, which was continued in the neighbouring Ahlbecker See until about 5000 cal. BP. The youngest layer of $\mathrm{CaCO}_{3}$-rich sediments there is calcareous gyttja (De Klerk 2005).

Stage 5: lagoon sedimentation with increasing human impact

Although the Wkrzańska Plain adjacent to Lake Nowowarpieńskie has been an attractive place for human activity since the late Palaeolithic (Kaiser et al. 2001), the anthropogenic geochemical signal appears relatively late in the sediments. Radiocarbon dating from the JNW1 core marks this moment at the end of the $14^{\text {th }}$ century, which coincides with the progressive settlement and economic activity in medieval Nowe Warpno. The development of fishery, agriculture and craftsmanship is reflected in the increase in contents of the studied microelements. Contemporary sedimentation is marked by the contamination of the surface sediments of the Nowowarpieńskie Lake. The highest content of $\mathrm{Cu}, \mathrm{Zn}$ and $\mathrm{Pb}$ is observed in the top $25 \mathrm{~cm}$ of the sediment core. The measured values are lower than in adjacent areas of the Great Lagoon, where the surface sediments are characterised by a significant clay fraction content that strongly accumulates heavy metals (Witkowski et al. 2009).

\section{Conclusions}

The results of the geochemical analyses carried out on the sediments of Lake Nowowarpieńskie provide new information on the post-glacial evolution of the environment in this part of today's Szczecin Lagoon.

The origin of the lake may be related to the melting of a block of dead ice, but the exact genesis requires further research. The initial basin depression was fed with rainwater, as reflected in the deposition of allochthonous mineral silt.

The thick layer of lacustrine chalk is a distinguishing feature of the studied body of water.
This specific element of the water body's sedimentary cover is the result of lake supply by groundwater with a high content of dissolved $\mathrm{CaCO}_{3}$. The source of carbonates was the glacial sediments of the Wkrzańska Plain and neighbouring area. The process of $\mathrm{CaCO}_{3}$ leaching from the glacial environment was initiated by the progressive decay of permafrost since the Allerød interstadial period. The thickness of deposited carbonate sediments, their internal structure and their chemical composition indicate the long duration or high efficiency of $\mathrm{CaCO}_{3}$ precipitation, conditioned by the high abundance of this substance in the rock environment.

The distinct bipartite lithological profile of the investigated sediments indicates two main sedimentation periods in the Nowowarpieńskie Lake: carbonate and post-carbonate sedimentation (gyttja). In the first, the water body exhibited development features very similar to the neighbouring lakes of the Wkrzańska Plain (e.g. lake Ahlbecker See). Their evolution was driven generally by climatic factors. The second stage of Nowowarpieńskie Lake's development was initiated by a palaeohydrological factor - the Littorina transgression. This resulted in the incorporation of the lake and its functioning to this day within the hydrological system of the Szczecin Lagoon.

\section{Acknowledgements}

The publication is related to the implementation of the project entitled "Origin of Lake Nowowarpieńskie and reconstruction of its natural development in relation to main Late-Glacial and Holocene environmental changes" financed by the National Science Centre, project number UMO-2016/21/N/ST10/02193.

\section{References}

Abraham J., Jose B., Jose A., Thomas S. 2020. Chapter 2 - Characterization of green nanoparticles from plants. In: N. Thajuddin, S. Mathew (eds) In micro and nano technologies. Phytonanotechnology: 21-39, DOI 10.1016/B978-0-12-8223482.00002-4.

AG Geologie der Staatlichen Geologischen Dienste: Geologische Kartieranleitung, Seekreide; 24.03.2021. Online: https://www.geokartieranleitung.de/Fachliche-Grundlagen/Genese/Petrogenetische-Gesteinsbezeichnung/Lockergesteine/entry/4693fbfc-f4a3-4a4a-8c01-dbcc9a6ecaac/mid/3427.

Borówka R.K. 2007. Geochemiczne badania osadów jeziornych strefy umiarkowanej. Studia Limnologica et Telmatologica 1,1: 33-42. 
Borówka R.K., Osadczuk A., Duda T., Woziński R., Kosińska B. 2003. Pokrywa osadowa Zalewu Szczecińskiego oraz obszaru ujściowego Odry. Prace Komisji Paleogeografii Czwartorzędu Polskiej Akademii Umiejętności I: 99-103.

Borówka R.K., Osadczuk A., Latałowa M., Duda T., Woziński R., Witkowski A., Święta-Musznicka J., Kosińska B. 2005a. Pokrywa osadowa Zalewu Szczecińskiego i jej wymowa paleogeograficzna. In: R.K. Borówka, S. Musielak (eds) Środowisko przyrodnicze wybrzėzy Zatoki Pomorskiej i Zalewu Szczecińskiego. Szczecin, Oficyna InPlus: 93-102.

Borówka R.K., Osadczuk A., Witkowski A., Wawrzyniak-Wydrowska B., Duda T. 2005b. Late Glacial and Holocene depositional history in the eastern part of the Szczecin Lagoon (Great Lagoon) basin - NW Poland. Quaternary International 130: 87-96.

Borówka R.K., Osadczuk A., Osadczuk K., Witkowski A., Skowronek A., Latałowa M., Mianowicz K. 2017a. Postglacial evolution of the Odra River Mouth, Poland-Germany. In: J. Harff (eds) Coastline changes of the Baltic Sea from South to East. Coastal Research Library 19: 193-217, DOI 10.1007/978-3-319-49894-2_10.

Borówka R.K., Skowronek A., Osadczuk A., Witkowski A., Maciąg Ł., Tomkowiak J., Bieniek B., Kosińska B. 2017b. Litologia i geochemia osadów wschodniej części Zalewu Szczecińskiego (Zalew Wielki). 85 Zjazd Polskiego Towarzystwa Geologicznego: Budowa geologiczna Południowego Battyku i Pomorza Środkowego oraz aktualne problemy geologii morza w perspektywie polskich badań oceanicznych. Warszawa: 43-50.

Bronk Ramsey C., Lee S. 2013. Recent and Planned Developments of the Program OxCal. Radiocarbon 55(2-3): 720-730.

Bukowska-Jania E. 2003. Rola systemu lodowcowego w obiegu węglanu wapnia w środowisku przyrodniczym. Wyd. UŚ, Katowice.

Chmal R., Karbowniczak A. 2015 (reambulation). Objaśnienia do Szczegółowej mapy geologicznej Polski 1:50 000, arkusz 151 Nowe Warpno, arkusz 1078 Nowe Warpno W. Państwowy Instytut Geologiczny-Państwowy Instytut Badawczy, Warszawa.

De Klerk P. 2005. A pollen diagram from the Ahlbecker Seegrund (Ueckermünder Heide, Vorpommern, NE Germany) from the legacy of Franz Fukarek. Archiv für Naturschutz und Landschaftsforschung: 93-103.

Dobracka E. 1980. Objaśnienia do Szczegółowej mapy geologicznej Polski 1:50 000, arkusz 151 Nowe Warpno, arkusz 1078 Nowe Warpno W. Państwowy Instytut Geologiczny-Państwowy Instytut Badawczy, Warszawa.

Herking C. 2002. Der menschliche Einfluß auf die Vegetation im Umkreis des Ahlbecker Sees und des
Kleinen Faulen Sees, Kreis Uecker-Randow, im Spiegel pollenanalytischer Untersuchungen. Archäologische Berichte aus Mecklenburg-Vorpommern 9: 16-25.

Jahns S., Herking C. 2002. Zur holozänen und spätpleistozänen Vegetationsgeschichte im westlichen Odergebiet. Römisch-Germanische Forschungen 60: 33-49.

Kaiser K., Endtmann E., Bogen C., Czakó-Pap S., Kühn P. 2001. Geoarchäologie und Palynologie spätpaleolithischer und mesolithischer Fundplätze in der Ueckermünder Heide, Vorpommern. Zeitschrift für Geologische Wissenschaften 29: 233244.

Khare T., Oak U., Shriram V., Verma S.K., Kumar V. 2019. Chapter 10 - Biologically synthesized nanomaterials and their antimicrobial potentials. In: K.S. Verma, A.K. Das (eds) Engineered Nanomaterials and Phytonanotechnology: Challenges for Plant Sustainability, Comprehensive Analytical Chemistry 87: 263-289, DOI 10.1016/bs.coac.2019.09.002

Markowski S. 1980. Struktura i właściwości podtorfowych osadów jeziornych rozprzestrzenionych na Pomorzu Zachodnim jako podstawa ich rozpoznawania i klasyfikacji. Materiały Konferencji nauk.-tech. „Kreda jeziorna i gytie”. Gorzów Wlkp. - Zielona Góra, luty 1980, 2: 44-55.

Mianowicz K. 2013 (unpublished). Zapis zmian środowiska przyrodniczego $\mathrm{w}$ subfosylnych osadach limnicznych i bagiennych w dolinie Dziwny (wyspa Wolin). Doctoral thesis, Szczecin.

Okupny D., Borówka R.K., Cedro B., Sławińska J., Tomkowiak J., Michczyński A., Kozłowska D., Kowalski K., Siedlik K. 2020. Geochemistry of a sedimentary section at the Wąwelnica archeological site, Szczecin Hills (Western Pomerania). Acta Geographica Lodziensia 110: 169-186, DOI 10.26485/AGL/2020/110/11

Osadczuk A. 2003. Zastosowanie metod akustycznych w rozpoznaniu środowiska sedymentacyjnego Zalewu Szczecińskiego. In: R.K. Borówka, A. Witkowski (eds) Człowiek i środowisko przyrodnicze pomorza Zachodniego, II Środowisko abiotyczne. Szczecin, Oficyna InPlus: 29-35.

Osadczuk A. 2004. Zalew Szczeciński - środowiskowe warunki współczesnej sedymentacji lagunowej. Uniwersytet Szczeciński Rozprawy $i$ Studia DCXXIII.

Pentecost A. 2009. The marl lakes of the British Isles. Freshwater Reviews 2: 167-197, DOI 10.1608/FRJ-2.2.4

Piechocki A., Wawrzyniak-Wydrowska B. 2016. Guide to freshwater and marine mollusca of Poland. Bogucki Wyd. Nauk., Poznań: 186-188.

Raven J.A., Smith F.A., Walker N.A. 1986. Biomineralization in the Charophyta sensu lato. In: Leadbeater B.S.C., Riding R. (eds) Biomineralization in Lower Plants and Animals, Clarendon Press, Oxford: 125-140. 
Reimer P.J., Baillie M.G.L., Bard E., Bayliss A., Beck J.W., Blackwell P.G., Bronk Ramsey C., Buck C.E., Burr G. ., Edwards R.L., Friedrich M., Grootes P.M., Guilderson T.P., Hajdas I., Heaton T.J., Hogg A G., Hughen K.A., Kaiser K.F., Kromer B., McCormac F.G., Manning S.W., Reimer R.W., Richards D.A., Southon J.R., Talam S., Turney C.S.M., van der Plicht J., Weyhenmeyer C.E. 2009. IntCal09 and Marine09 radiocarbon age calibration curves, 0-50,000 years cal BP. Radiocarbon 51(4): 1111-1150.

Rutkowski J. 2007. Osady jezior w Polsce. Charakterystyka i stan rozpoznania, metodyka badań, propozycje. Studia Limnologica et Telmatologica 1,1: 17-24.

Schäfer A. 1973. Zur Entstehung von Seekreide Untersuchungen am Untersee (Bodensee). N. Jb. Geol. Paläont. Mh. 4: 216-230.

Solon J., Borzyszkowski J., Bidłasik M., Richling A., Badora K., Balon J., Brzezińska-Wójcik T., Chabudziński Ł., Dobrowolski R., Grzegorczyk I., Jodłowski M., Kistowski M., Kot R., Krąż P., Lechnio J., Macias A., Majchrowska A., Malinowska E., Migoń P., Myga-Piątek U., Nita J.,
Papińska E., Rodzik J., Strzyż M., Terpiłowski S., Ziaja W. 2018. Physico-geographical mesoregions of Poland: verification and adjustment of boundaries on the basis of contemporary spatial data. Geographia Polonica 91,2: 143170, DOI 10.7163/GPol.0115

Walker N.A. 1983. The uptake of inorganic carbon by aquatic plants. Plant Cell Environment 6: 323328.

Witkowski A., Borówka R.K., Bąk M., Olas M., Lutyńska M., Wawrzyniak-Wydrowska B., Osadczuk A., Tomkowiak J. 2003. Zmiany środowiskowe w Zalewie Szczecińskim w późnym glacjale i holocenie w świetle analizy okrzemkowej. In: R.K. Borówka, A. Witkowski (eds) Człowiek $i$ środowisko przyrodnicze Pomorza Zachodniego, II Środowisko abiotyczne. Szczecin, Oficyna InPlus: 36-41.

Witkowski A., Skowronek, A., Borówka, R., Osadczuk A. 2009. Lithogenesis and geochemistry of the Szczecin Lagoon's sediments. Research Report for National Fund for Environmental Protection and Water Management, University of Szczecin. 